\title{
Membrane regulation of the chromosomal replication activity of E.coli DnaA requires a discrete site on the protein
}

\section{Jennifer Garner and Elliott Crooke'}

Department of Biochemistry and Molecular Biology,

Georgetown University Medical Center, Washington, DC 20007, USA

${ }^{1}$ Corresponding author

The capacity of DnaA protein to initiate DNA synthesis at the chromosomal origin is influenced profoundly by the tightly bound nucleotides ATP and ADP. Acidic phospholipids can catalyze the conversion of inactive ADP-DnaK protein into the active ATP form. Proteolytic fragments of the nucleotide form of DnaA protein were examined to determine regions of the protein critical for functional interaction with membranes. A $35 \mathrm{kDa}$ chymotryptic and $29 \mathrm{kDa}$ tryptic fragment retained the tightly bound nucleotide. The fragments, whose amino-termini are within three residues of each other, but differ at their carboxyl ends, showed strikingly different behavior when treated with acidic phospholipids. The larger chymotryptic fragment released the bound nucleotide in the presence of acidic, but not neutral phospholipids. In contrast, the smaller tryptic fragment was inert to both forms of phospholipids. Acidic membranes, but not those composed of neutral phospholipids, protect from tryptic digestion a small portion of the segment that constitutes the difference between the 29 and $35 \mathrm{kDa}$ fragments. The resulting $30 \mathrm{kDa}$ tryptic fragment, which possesses this protected region, interacts functionally with acidic membranes to release the bound effector nucleotide. Inasmuch as the anionic ganglioside $\mathbf{G M}_{1}$, a compound structurally dissimilar to acidic glycerophospholipids, efficiently releases the nucleotide from DnaA protein, an acidic surface associated with a hydrophobic environment is the characteristic of the membrane that appears crucial for regulatory interaction with DnaA protein.

Keywords: DnaA/E.coli/membranes/oriC/replication

\section{Introduction}

DnaA protein binds the unique origin, oriC, to initiate a cycle of chromosomal replication in Escherichia coli (Skarstad and Boye, 1994). Formation of an initial complex, comprised of origin DNA wrapped around a cluster of 20 DnaA molecules (Funnel et al., 1986; Crooke et al., 1993) is the first discernible stage of initiation (Sekimizu et al., 1988a). In the presence of ATP and architectural proteins HU or IHF, DnaA protein in the initial complex promotes strand opening of the AT-rich 13 mer repeats in oriC to form an open complex (Bramhill and Kornberg, 1988; Hwang and Kornberg, 1992). Assembly of replisomes at the two forks gives rise to bidirectional replication (Marians, 1992).
The transition from an initial complex to an open complex in vitro is influenced profoundly by the high affinity binding of ATP or ADP to DnaA protein $\left[K_{\mathrm{d}}=\right.$ $0.03 \mu \mathrm{M}$ and $0.1 \mu \mathrm{M}$, respectively (Sekimizu et al., 1987)]. While both forms are capable of forming initial complexes (Yung and Kornberg, 1989; Crooke et al., 1993), only ATP-DnaK is efficient at catalyzing duplex melting; the ADP form is feeble (Sekimizu et al., 1987; Yung et al., 1990). In a DNA-dependent manner, complexed ATP is hydrolyzed slowly to ADP, which remains tightly bound and renders DnaA protein inactive for initiation. Thus, after initiating a round of replication, DnaA protein must be rejuvenated to the ATP form if it is to participate in subsequent initiations.

Acidic phospholipids in a fluid bilayer promote the release of bound ADP and ATP from DnaA protein in vitro (Sekimizu and Kornberg, 1988; Yung and Kornberg, 1988; Crooke et al., 1992; Castuma et al., 1993). No distinctions have been observed between the phospholipid-mediated release of bound ADP versus ATP. However, the cellular concentrations of the nucleotides $(\sim 250 \mu \mathrm{M}$ and $3 \mathrm{mM}$, respectively) are such that, if rebinding of free nucleotide were to occur, formation of ATP-DnaK protein is highly favored. In support, when ADP-DnaK protein is stabilized by oriC, acidic phospholipids can facilitate an exchange of ATP for ADP, and thus restore initiation activity to DnaA protein in vitro (Sekimizu and Kornberg, 1988; Crooke et al., 1992). The molecular nature of the concerted interaction between ADP-DnaK protein, oriC and acidic phospholipids remains unclear.

Normal cellular levels of acidic phospholipids apparently are required to sustain chromosomal replication from oriC in vivo (Xia and Dowhan, 1995). A strain of E.coli was constructed so that the chromosomal phosphatidylglycerophosphate synthase gene (pgsA) is under inducible control (Heacock and Dowhan, 1989). This synthase catalyzes the committed step in the synthesis of the acidic phospholipids. Growth of this strain is absolutely dependent on the presence of the inducer IPTG. Removal of IPTG from a fully induced culture causes growth arrest with a concomitant 10 -fold reduction in the combined levels of acidic phospholipids (Heacock and Dowhan, 1989). These cells remain viable; re-addition of IPTG, even after several hours, results in acidic phospholipid synthesis and consequent cell growth. To determine if the coincident growth arrest seen with reduced levels of acidic phospholipids is due to impaired activation of DnaA protein, conditions that bypass the requirement for DnaA protein in initiating replication were employed. In the absence of RNase HI, initiations of DNA replication independent of DnaA protein occur (constitutive stable DNA replication) at sites other than oriC in a recAdependent manner (Torrey et al., 1984; von Meyenburg et al., 1987). Null alleles of the $d n a A$ gene and deletions 


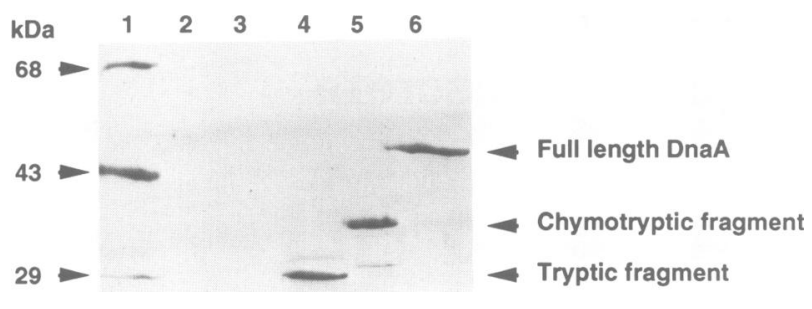

Fig. 1. Proteolysis of ATP-DnaK protein produces stable fragments. ATP-DnaK protein $(28 \mu \mathrm{l}$ buffer A) was subjected to limited proteolysis $\left(30 \mathrm{~min}, 16^{\circ} \mathrm{C}\right)$ by chymotrypsin $(10 \mu \mathrm{g}$ DnaA, $6 \mathrm{mU})$ or trypsin $(20 \mu \mathrm{g}$ DnaA, $0.75 \mathrm{U})$. Proteolysis was quenched by addition of aprotinin (10-fold weight excess over protease) and fragments were separated by SDS-PAGE (15\%) and stained with Coomassie brilliant blue. Lane 1, molecular weight markers; lane $2,6.5 \mu \mathrm{g}(0.75 \mathrm{U})$ trypsin; lane $3,0.8 \mu \mathrm{g}(6 \mathrm{mU})$ chymotrypsin; lane 4 , tryptic fragment; lane 5 , chymotryptic fragment; lane $6,3 \mu \mathrm{g}$ DnaA protein.

of oriC are suppressed by point mutations and null alleles of $r n h A$ (Ogawa et al., 1984). Thus, mutations in $r n h A$ should also allow growth in cells deficient for acidic phospholipids if the primary site of growth limitation is the inability to activate DnaA protein through phospholipid rejuvenation. In agreement, a $r n h A^{-}, r e c A^{+}$derivative of this strain continues to grow (instead of arresting growth) in the absence of IPTG due to constitutive DNA replication, and indicates the dependency of normal initiations on acidic phospholipids (Xia and Dowhan, 1995).

DnaA protein has been divided into four domains (Figure 3; Fujita et al., 1992). However, this definition is based on sequence conservation of the protein among various species of enterobacteriaceae. Recently, the localization of a functional site of DnaA protein, that responsible for binding oriC DNA, has been described (Roth and Messer, 1995). The 94 carboxy amino acids of DnaA protein appear to be necessary and sufficient to bind origin DNA. Sequence analysis and examination of isolated mutant forms of DnaA protein suggest that a segment which includes Ala184 is involved in the high affinity binding of ADP and ATP (Hwang and Kaguni, 1988a,b; Hansen et al., 1992; Skarstad and Boye, 1994), although this has not been demonstrated directly. Thus, other than the domain for DNA binding, little is known about the location of sites on DnaA protein responsible for critical initiation functions.

Here we describe studies which identify a domain of DnaA protein necessary for membrane reactivation of the protein's initiation activity. A discrete region of DnaA protein appears essential for the acidic phospholipidmediated exchange of the regulatory molecules ATP and ADP. Features of the membranes necessary for interaction with DnaA protein are also presented.

\section{Results}

\section{Bound ATP stabilizes proteolytic fragments during digestion of DnaA protein}

Proteolysis conditions were sought such that full-length DnaA protein would be consumed completely, commensurate with the generation of stable intermediate size fragments containing an active, high affinity ATP binding site. Nevertheless, limited tryptic and chymotryptic digestions of nucleotide-free DnaA protein yielded only
Table I. Stoichiometries of ATP bound by the tryptic and chymotryptic fragments and full-length DnaA protein

\begin{tabular}{llll}
\hline DnaA & Fragment $(\mathrm{pmol})$ & ATP $(\mathrm{pmol})$ & ATP/fragment \\
\hline Full-length & 4.65 & 2.76 & $0.59 \pm 0.025$ \\
Chymotryptic & 3.09 & 1.67 & $0.54 \pm 0.024$ \\
Tryptic & 3.40 & 1.84 & $0.54 \pm 0.010$ \\
\hline
\end{tabular}

Radiolabeled ATP-DnaK protein $(9 \mu \mathrm{g} ; 45 \mu \mathrm{l}$ buffer A) was digested $\left(30 \mathrm{~min}, 16^{\circ} \mathrm{C}\right)$ with trypsin $(1.1 \mathrm{U})$ or chymotrysin $(5.4 \mathrm{mU})$. Digestions were stopped by addition of a 10-fold weight excess of aprotinin. A portion of the reactions $(1 \mu \mathrm{l}$, in duplicate) was spotted on a nitrocellulose filter to measure protein-bound ATP (see Materials and methods) and compared with the ATP binding of full-length DnaA protein. Peptides in samples of the reactions ( $38 \mu \mathrm{l}$ chymotryptic, $40 \mu \mathrm{l}$ tryptic, $10 \mu \mathrm{l}$ full-length DnaA) were resolved by SDS-PAGE (15\%) and transferred to PVDF membranes (see Materials and methods). Bands (visualized by staining with Coomassie brilliant blue) which corresponded to full-length DnaA and the 35 and $29 \mathrm{kDa}$ framents were excised from the membrane and analyzed for amino acid content. Values are normalized for $1 \mu \mathrm{g}$ of full-length DnaA protein, based on Bradford assay.

unstable, transient fragments (data not shown). Treatment of the ATP form of DnaA protein with each protease, however, produced a prominent fragment (Figure 1). Digestion with trypsin generated a polypeptide with an apparent mol. wt of $29 \mathrm{kDa}$ (lane 4), while a larger fragment (apparent mol. wt of $35 \mathrm{kDa}$ ) was formed during proteolysis with chymotrypsin (lane 5). Residual fulllength DnaA protein cannot be detected in either digestion mixture (lanes 4 and 5).

\section{The predominant proteolytic fragments retain the tightly bound ATP}

The ATP bound to DnaA protein remained associated with proteolytic fragments in the tryptic and chymotrytic digestions as determined by filter retention assays. The nucleotide binding characteristics of the proteolytic fragments are similar to those for full-length DnaA protein. These include the ATP remaining bound for comparable periods of time over a variety of temperatures $\left(0-38^{\circ} \mathrm{C}\right)$, as well as through several cycles of freeze-thawing, even when challenged with excess ATP in solution (data not shown).

The major chymotryptic and tryptic fragments accumulate only when the starting DnaA protein is in its ATP form. Therefore, those fragments were considered likely candidates for the retention of bound ATP. The molar ratios between protein-bound ATP and the isolated $35 \mathrm{kDa}$ chymotryptic and $29 \mathrm{kDa}$ tryptic fragments were measured (Table I). Both the predominant tryptic and chymotryptic fragments have stoichiometries of $\sim 0.5$ with protein-bound ATP, values analogous to that seen for full-length DnaA protein (Table I; Sekimizu et al., 1987). No other single proteolytic fragment is present in quantities high enough to account for the levels of protein-bound ATP, although a combination of minor species could give comparable stoichiometries.

To determine independently which fragments retained bound ATP, products of the digestion mixtures were resolved by anion-exchange chromatography. For the chymotrypsin digestion, two peaks of protein-bound ATP were observed; one in the flow-through fractions, another eluting at $\sim 200 \mathrm{mM} \mathrm{KCl}$ (Figure 2A). The proteolytic 
A

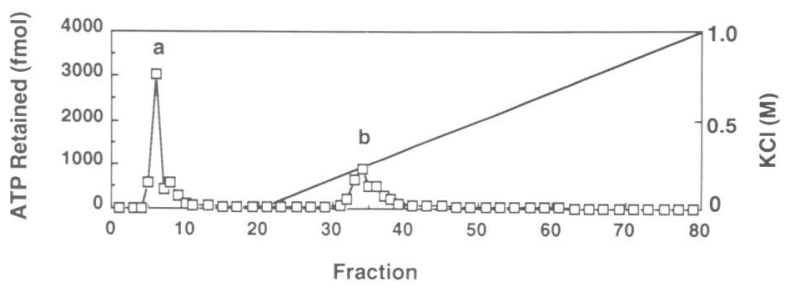

B

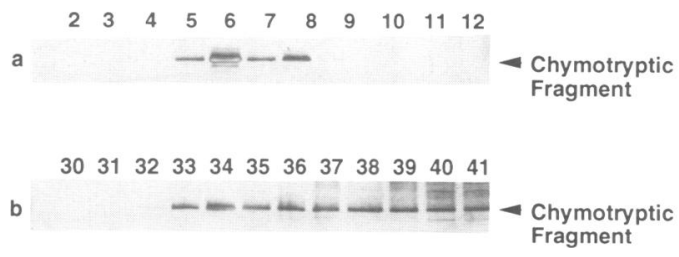

Fig. 2. The prominent chymotryptic fragment co-purifies with proteinbound ATP. [ $\left.{ }^{32} \mathrm{P}\right]$ ATP-DnaK protein [ $60 \mu \mathrm{g}, 200 \mu \mathrm{l}$ buffer $\mathrm{Q}$ (buffer $\mathrm{A}, \mathrm{pH} 8.4)$ ] was digested $\left(30 \mathrm{~min}, 16^{\circ} \mathrm{C}\right)$ with chymotrypsin $(36 \mathrm{mU})$. Proteolysis was quenched by addition of aprotinin (10-fold weight excess). The digestion reaction was loaded $(0.05 \mathrm{ml} / \mathrm{min})$ onto a $1 \mathrm{ml}$ Mono-Q column equilibrated in buffer $\mathrm{Q}\left(4^{\circ} \mathrm{C}\right)$. The column was washed with $3 \mathrm{ml}$ of buffer $\mathrm{Q}$ and bound proteins were eluted with a $0-1 \mathrm{M} \mathrm{KCl}$ gradient $(15 \mathrm{ml} ; 0.2 \mathrm{ml} / \mathrm{min} ; 0.25 \mathrm{ml} /$ fraction).

(A) Samples $(25 \mu \mathrm{l})$ of column fractions were assayed by filter retention for protein-bound ATP. Fractions 1-20, which include peak ' $a$ ', are flow-through fractions. Peak ' $b$ ' is included in the elution gradient fractions, 21-80. (B) Peptides in samples $(100 \mu 1)$ from peaks ' $a$ ' and ' $b$ ' were resolved by SDS-PAGE and visualized by silver stain. Arrows indicate migration of the prominent chymotryptic DnaA fragment (Figure 1).

fragment with an apparent mass of $35 \mathrm{kDa}$ was detected in both peaks, proportional to the amount of protein-bound ATP, and was not observed in fractions lacking proteinbound ATP. Similar co-purification of the $29 \mathrm{kDa}$ fragment and protein-bound ATP was observed for the tryptic digestion (data not shown).

A third means to identify fragments having bound nucleotide was provided by cross-linking of a photoactivatible radiolabeled ATP analog to full-length DnaA protein prior to proteolysis. Cross-linking reactions were quenched, the protein was subjected to partial proteolytic digestion and the resulting polypeptides separated by SDS-PAGE. Autoradiography revealed only bands with migrations indistinguishable from those for the predominant tryptic and chymotryptic fragments (data not shown).

\section{The tryptic and chymotryptic fragments differ at their carboxy-termini}

The chymotryptic and tryptic fragments responsible for bound nucleotide were analyzed for amino-terminal sequence and mass in order to map their locations within DnaA protein. The $\mathrm{N}$-termini of the fragments are in close proximity, at residues Ser115 (tryptic) and Asp118 (chymotryptic); thus, both are missing the N-terminal 25\% of full-length DnaA protein. Mass spectroscopy data suggest the tryptic fragment has a mass of $29220 \mathrm{Da}$; this value is in agreement with the predicted mass of a fragment (29 $111 \mathrm{Da}$ ) with a carboxy-terminus at Lys372 of DnaA protein (Figure 3). For comparison, cleavage at the nearest tryptic sites flanking Lys372 would generate fragments of $28074 \mathrm{Da}$ (Arg364) or $30136 \mathrm{Da}$ (Lys381).

The mass of the chymotryptic fragment, as estimated

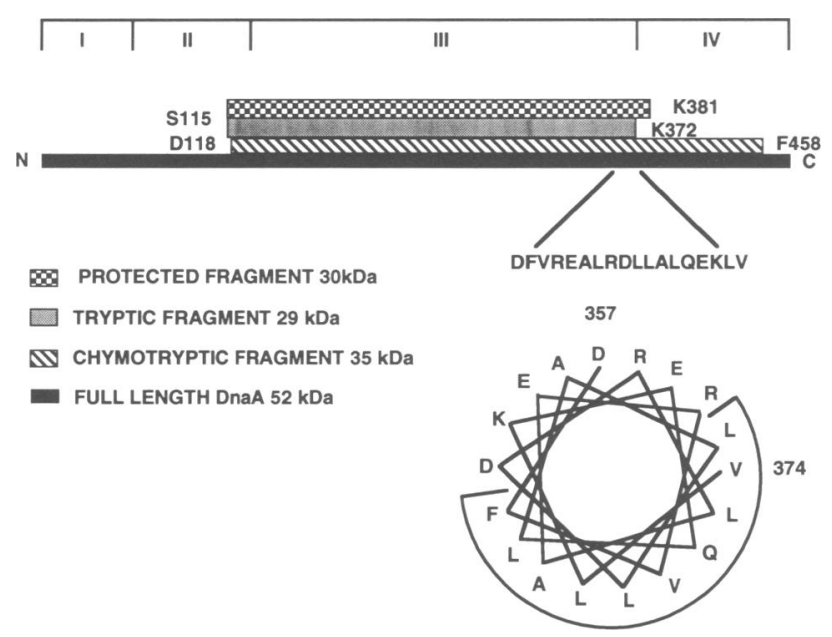

Fig. 3. Identification of the tryptic, chymotryptic and the phosphatidylglycerol (PG)-protected tryptic fragments. ATP-DnaK $\left(6.75 \mu \mathrm{g}, 67.5 \mu \mathrm{l}\right.$ buffer A) was treated $\left(30 \mathrm{~min}, 16^{\circ} \mathrm{C}\right)$ with trypsin $(0.95 \mathrm{U})$ or chymotrypsin $(4.3 \mathrm{mU})$. Digestions were inhibited by addition of aprotinin (10-fold weight excess). Fragments were separated by SDS-PAGE (15\%) and transferred to PVDF membrane (see Materials and methods). Following Coomassie staining, the fragment bands were excised and subjected to Edman degradation (see Materials and methods). The PG-protected tryptic fragment was prepared by incubating ATP-DnaK protein $(0.5 \mathrm{mg}, 0.75 \mathrm{ml}$ buffer A) with PG vesicles $\left(5 \mu \mathrm{mol}, 10 \mathrm{~min}, 16^{\circ} \mathrm{C}\right)$ before digesting with trypsin $\left(24.2 \mathrm{U}, 30 \mathrm{~min} 16^{\circ} \mathrm{C}\right)$. Following inhibition of the protease by addition of aprotinin $(100 \mu \mathrm{g})$, polypeptides were precipitated by the addition of $\mathrm{CHCl}_{3}: \mathrm{MeOH}(1: 3,114 \mathrm{ml})$ and collected by centrifugation $\left(27000 \mathrm{~g}, 60 \mathrm{~min}, 4^{\circ} \mathrm{C}\right)$. Precipitated fragments were dissolved in $1 \%$ SDS, $0.1 \%$ TFA $(500 \mu \mathrm{l})$ and purified by reverse phase HPLC (see Materials and methods). The isolated fragment was subjected to Edman degradation to identify the $\mathrm{N}$-terminal sequence. To determine the molecular weight of the tryptic and chymotryptic fragments by mass spectroscopy, the fragments were generated (30 $\mu \mathrm{g}$ DnaA protein, $1 \mathrm{U}$ trypsin, $100 \mu \mathrm{l}$ buffer $\mathrm{A} ; 30 \mu \mathrm{g}$ DnaA protein, $37.5 \mathrm{mU}$ chymotrypsin, $100 \mu \mathrm{l}$ buffer A) and then purified by reverse phase HPLC (see Materials and methods). The isolated fragments were analyzed using a Kratos Kompact MALDI 3. A helical wheel projection of a potential amphipathic helix (G.von Heijne, personal communication; Skarstad and Boye, 1994) involving residues 357374 , and the four consensus sequence domains of DnaA protein (Fujita et al., 1992) are shown.

by SDS-PAGE, is $35 \mathrm{kDa}$. A mass of $35043 \mathrm{Da}$ is predicted for a fragment between Asp118 and Phe458. Mass spectroscopy data also suggest the location of the carboxy-terminus as Phe458; under the non-reducing conditions used to prepare the sample for mass spectroscopy (see Materials and methods), the formation of a disulfide bond between the Asp118-Phe458 fragment (35 $043 \mathrm{Da})$ and the fragment corresponding to Met1Tyr41 (4778 Da) would give rise to a peptide with a predicted mass of $39821 \mathrm{Da}$, a value in agreement with the mass spectroscopy value of $39835 \mathrm{Da}$.

\section{The proteolytic fragments fail to bind oric and initiate replication}

ATP-DnaK protein was digested with chymotrypsin and trypsin to produce the 35 and $29 \mathrm{kDa}$ fragments, respectively. The proteolysis reactions were terminated by the addition of a protease inhibitor, and the replicative activities of the fragments in the proteolysis mixtures were assessed. Both the $35 \mathrm{kDa}$ chymotryptic and $29 \mathrm{kDa}$ tryptic fragments are unable to initiate in vitro replication of oriC plasmids or single-stranded DNA that contains a 


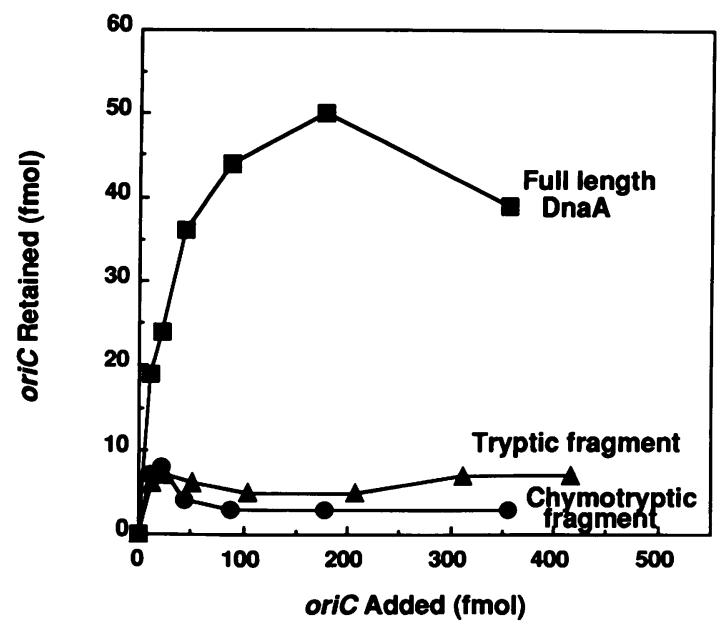

Fig. 4. The chymotryptic and the tryptic fragments of ATP-DnaK are unable to bind oriC. $\left[{ }^{3} \mathrm{H}\right] \mathrm{pBS}$ oriC was added to mixtures $(16 \mu \mathrm{l})$ that contained ATP-DnaK protein $(2.5 \mu \mathrm{g})$ or ATP-DnaK protein $(2.5 \mu \mathrm{g})$ digested with trypsin $\left(0.29 \mathrm{U}, 16^{\circ} \mathrm{C}, 30 \mathrm{~min}\right)$, or chymotrypsin $(2 \mathrm{mU}$, $16^{\circ} \mathrm{C}, 30 \mathrm{~min}$ ). Samples were incubated with labeled DNA (10 min, $25^{\circ} \mathrm{C}$ ) and then filtered through nitrocellulose. Filters were washed, and retained DNA was measured by liquid scintillation counting.

DnaA binding hairpin ( $\mathrm{ABC}$ primosome system, Masai et al., 1990). In contrast, mock-digested DnaA protein was virtually identical to untreated DnaA protein, an indication that neither the proteases nor the inhibitor had a deleterious effect on the replication reactions (data not shown). Furthermore, neither fragment was capable of binding oriC, in contrast to full-length DnaA protein (Figure 4). Inasmuch as the 94 carboxy amino acids of DnaA protein (domain IV) have been shown to be necessary and sufficient for specific interaction with 9 mer DnaA boxes (Roth and Messer, 1995), it is of interest that the chymotryptic fragment fails to bind oriC plasmids in filter retention assays. This further indicates that the nine amino acids at the carboxy-terminus of DnaA protein may have been removed from the chymotryptic fragment.

\section{The chymotryptic fragment responds specifically to acidic phospholipids}

Incubation of ADP- or ATP-DnaK protein with acidic phospholipids in a fluid bilayer releases the tightly bound nucleotides (Sekimizu and Kornberg, 1988; Yung and Kornberg, 1988; Crooke et al., 1992; Castuma et al., 1993). The $35 \mathrm{kDa}$ chymotryptic and $29 \mathrm{kDa}$ tryptic fragments with bound radiolabeled ATP were examined for their response to treatment with acidic versus neutral phospholipids. The chymotryptic fragment, like full-length DnaA protein, released bound nucleotide when mixed with phosphatidylglycerol, but not with phosphatidylcholine (Figure 5). In contrast, $\sim 85 \%$ or more of the ATP remained tightly bound to the tryptic fragment when exposed to vesicles composed of either phospholipid (Figure 5).

\section{Acidic phospholipids protect a domain of DnaA protein from tryptic cleavage}

ATP-DnaK protein was mixed with phospholipid vesicles before exposure to trypsin to determine if membranes are able to protect portions of the protein from proteolysis. The mixtures were incubated at $16^{\circ} \mathrm{C}$ to minimize release of bound nucleotide. This temperature, while above the

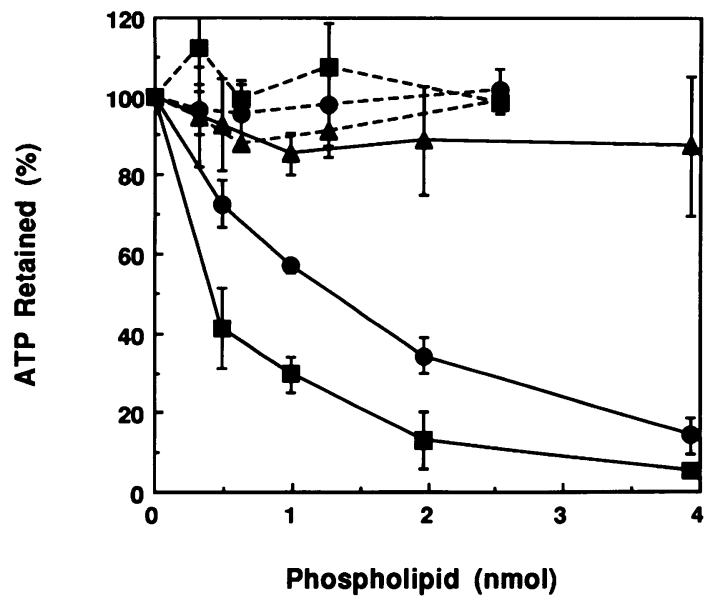

Fig. 5. The chymotryptic fragment retains specificity for acidic phospholipids, the tryptic does not. [ $\left.{ }^{32} \mathrm{P}\right] \mathrm{ATP}-\mathrm{DnaK}$ protein $(0.2 \mu \mathrm{g}$; $16 \mu$ l buffer A) was subjected to limited proteolysis $\left(16^{\circ} \mathrm{C}, 30 \mathrm{~min}\right)$ by chymotrypsin $(0.12 \mathrm{mU}, 0)$ or trypsin $(24 \mathrm{mU}, \boldsymbol{\Delta})$ to produce the stable fragments. After inhibiting proteolysis with aprotinin (10-fold weight excess), the fragments and undigested $\left[{ }^{32} \mathrm{P}\right] \mathrm{ATP}-\mathrm{DnaK}$ protein (口) were treated $\left(10 \mathrm{~min}, 38^{\circ} \mathrm{C}\right)$ with neutral $(----)$ or acidic $(-)$ phospholipid small unilamellar vesicles (see Materials and methods). Samples were filtered through nitrocellulose filters and retained ATP was quantitated by liquid scintillation counting. Values of $100 \%$ correspond to the ATP retained by the full-length DnaA protein or the fragments incubated at $38^{\circ} \mathrm{C}$ in the absence of phospholipid.

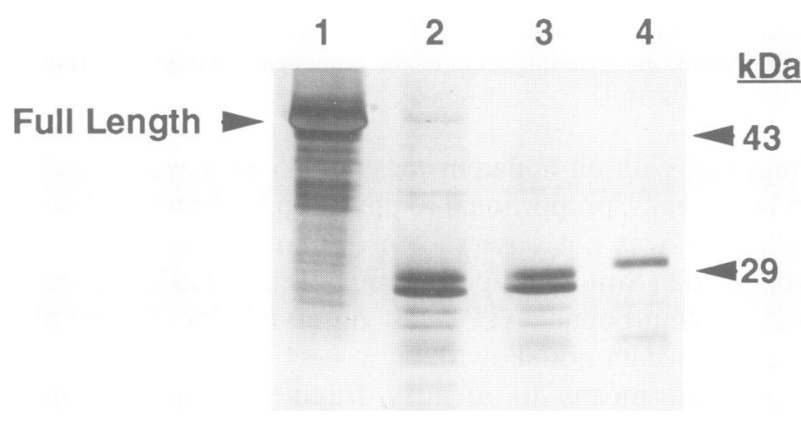

Fig. 6. Acidic phospholipids protect a region of ATP-DnaK from tryptic cleavage. ATP-DnaK protein $(3 \mu \mathrm{g}$; lane 1$)$ was incubated $\left(256 \mu \mathrm{l}\right.$ buffer $\mathrm{A}, 10 \mathrm{~min}, 16^{\circ} \mathrm{C}$ ) with phosphatidylcholine vesicles (37 nmol; lane 3 ), phosphatidylglycerol vesicles $(38 \mathrm{nmol}$; lane 4$)$ or buffer (lane 2$)$ before digestion with trypsin $\left(0.36 \mathrm{U}, 30 \mathrm{~min}, 16^{\circ} \mathrm{C}\right)$. Digestion was stopped by the addition of aprotinin $(7.2 \mu \mathrm{g})$.

Polypeptides were precipitated by the addition of $\mathrm{CHCl}_{3}: \mathrm{MeOH}(1: 3$, $800 \mu \mathrm{l})$ and collected by centrifugation $\left(14000 \mathrm{~g}, 20 \mathrm{~min}, 4^{\circ} \mathrm{C}\right)$. Precipitated fragments were dissolved in SDS, separated by SDSPAGE $(15 \%)$ and visualized by silver stain.

phase transition temperature for the phospholipids employed, does not impart the level of fluidity necessary for nucleotide release (Castuma et al., 1993). Exposure of ATP-DnaK protein to phosphatidylcholine prior to digestion has no effect on the generation of the $29 \mathrm{kDa}$ tryptic fragment (Figure 6, lane 3); the products generated are indistinguishable from those produced in the absence of phospholipids [under the more dilute conditions of this experiment, a doublet is observed (Figure 6, lane 2)]. In sharp contrast, incubation of ATP-DnaK protein with phosphatidylglycerol clearly alters its digestion by trypsin. A fragment with an apparent $M_{r}$ of $30 \mathrm{kDa}$ becomes the prominent proteolytic product (Figure 6, lane 4), and the $29 \mathrm{kDa}$ fragment generated in reactions lacking acidic phospholipids is not detectable. Peptide sequencing reveals 
Table II. The $30 \mathrm{kDa}$ fragment responds to acidic lipid treatment

\begin{tabular}{|c|c|c|c|c|c|}
\hline & $\begin{array}{l}\text { 1st treatment } \\
\left(16^{\circ} \mathrm{C}\right)\end{array}$ & $\begin{array}{l}\text { 2nd treatment } \\
\left(16^{\circ} \mathrm{C}\right)\end{array}$ & $\begin{array}{l}\text { Incubation } \\
(10 \mathrm{~min})\end{array}$ & $\begin{array}{l}\text { ATP bound } \\
\text { (fmol) }\end{array}$ & $\begin{array}{l}\text { ATP retained } \\
(\%)\end{array}$ \\
\hline A & trypsin, $30 \mathrm{~min}$ & PG, $10 \mathrm{~min}$ & $16^{\circ} \mathrm{C}$ & 312 & 100 \\
\hline B & trypsin, $30 \mathrm{~min}$ & $\mathrm{PG}, 10 \mathrm{~min}$ & $38^{\circ} \mathrm{C}$ & 378 & 121 \\
\hline $\mathrm{C}$ & PG, $10 \mathrm{~min}$ & trypsin, $30 \mathrm{~min}$ & $16^{\circ} \mathrm{C}$ & 237 & 76 \\
\hline D & PG, $10 \mathrm{~min}$ & trypsin, $30 \mathrm{~min}$ & $38^{\circ} \mathrm{C}$ & 46 & 0 \\
\hline E & \multicolumn{2}{|c|}{ no DnaA protein } & & 51 & - \\
\hline
\end{tabular}

Reactions A and B: ATP-DnaK protein $\left(4 \mu \mathrm{g}, 312 \mu \mathrm{l}\right.$ buffer A) was digested with trypsin $\left(0.48 \mathrm{U}, 16^{\circ} \mathrm{C}\right)$ and then treated with phosphatidylglycerol $\left(48 \mathrm{nmol}, 16^{\circ} \mathrm{C}\right)$. Reactions $\mathrm{C}$ and D: ATP-DnaK protein $\left(4 \mu \mathrm{g}, 312 \mu \mathrm{l}\right.$ buffer A) was treated with phosphatidylglycerol $\left(48 \mathrm{nmol}, 16^{\circ} \mathrm{C}\right)$ followed by digestion with trypsin $\left(0.48 \mathrm{U}, 16^{\circ} \mathrm{C}\right)$. Each mixture was then incubated for $10 \mathrm{~min}\left(16^{\circ} \mathrm{C}\right.$, reactions $\mathrm{A}$ and $\mathrm{C} ; 38^{\circ} \mathrm{C}$, reactions $\mathrm{B}$ and $\left.\mathrm{D}\right)$. Samples ( $1 / 10$ reaction volume, in duplicate) were assayed by filter retention (see Materials and methods) to measure the amount of protein-bound ATP remaining. The remainder of the reactions were resolved by SDS-PAGE (15\%) to confirm the presence of the 29 and $30 \mathrm{kDa}$ fragments and the absence of full-length DnaA protein.

that the 29 and $30 \mathrm{kDa}$ fragments share a common aminoterminus (Ser115 of full-length DnaA protein). Thus, interaction with acidic phospholipids appears to protect a site within DnaA protein (Lys372) normally cleaved by trypsin. SDS-PAGE data suggest that the carboxyterminus of the larger tryptic fragment (Figure 6, lane 4) corresponds to residue Lys381 (i.e. fragment mass of $30136 \mathrm{Da}$ ), the next cleavage site following Lys372 of DnaA protein (Figure 3). The next closest trypsin cleavage site after Lys381 is Lys388, which would produce a fragment of $30991 \mathrm{Da}$.

\section{The tryptic fragment containing an additional $1 \mathrm{kDa}$ of sequence at the carboxy-terminus responds to acidic phospholipids}

Acidic phospholipids are able to protect a region of DnaA protein from proteolytic digestion (Figure 6). This region is absent in the $29 \mathrm{kDa}$ fragment, which is inert to acidic phospholipids, but is present in the $35 \mathrm{kDa}$ fragment, which releases bound nucleotide upon treatment with acidic phospholipids (Figure 3). Thus, the importance of this portion of DnaA protein for functional interaction with membranes was examined.

The region of interest constitutes the difference between the 29 and $30 \mathrm{kDa}$ tryptic fragments (Figure 3). Digestion of ATP-DnaK protein with trypsin produces the $29 \mathrm{kDa}$ fragment which retains bound nucleotide in the presence of acidic phospholipids, even at the elevated temperature of $38^{\circ} \mathrm{C}$ (Table II, lines A and B; see also Figure 5). Generation of the $30 \mathrm{kDa}$ fragment includes first incubating ATP-DnaK protein with acidic phospholipids at $16^{\circ} \mathrm{C}$ before addition of trypsin. At this temperature, more than half $(56 \%)$ of the nucleotide remains bound to full-length protein, as opposed to nearly complete nucleotide release (5\% retained) with incubation at $38^{\circ} \mathrm{C}$.

The subsequent digestion of membrane-associated ATPDnaK protein by trypsin produces the $30 \mathrm{kDa}$ fragment (Figure 6), which retains its bound nucleotide in the presence of acidic phospholipids at $16^{\circ} \mathrm{C}$ (Table II, line C). However, when the mixture of the $30 \mathrm{kDa}$ fragment and phosphatidylglycerol is incubated at $38^{\circ} \mathrm{C}$, a considerable portion of the bound nucleotide is released (Table II, line D). In contrast, the $29 \mathrm{kDa}$ fragment retains bound ATP in the presence of acidic membranes regardless of the temperature (Table II, lines A and B).

\section{DnaA protein releases bound nucleotide when exposed to acidic gangliosides}

A detailed understanding of the membrane binding site of DnaA protein requires an understanding of the pertinent chemical and structural features of the corresponding membranes. The characteristics of the lipids necessary for functional interaction with DnaA protein are understood only to the extent that phospholipid species which possess anionic polar head groups (Sekimizu and Kornberg, 1988; Castuma et al., 1993) and reside in a fluid bilayer (Yung and Kornberg, 1988; Crooke et al., 1992; Castuma et al., 1993) are capable of releasing bound nucleotide from DnaA protein. To define relevant features of the lipids better, ATP-DnaK protein was treated with mixed gangliosides. DnaA protein responds to them in a manner comparable with that when it is incubated with phosphatidylglycerol (Figure 7A). Inasmuch as mixed gangliosides are active at releasing bound nucleotide, the action of defined ganglioside species was examined. While the acidic ganglioside $\mathrm{GM}_{1}$ is potent at dissociating nucleotide from DnaA protein, a derivative which differs from $\mathrm{GM}_{1}$ only in that it lacks the sialic acid moiety, is inert (Figure 7B).

The $35 \mathrm{kDa}$ chymotryptic and $29 \mathrm{kDa}$ tryptic fragments of DnaA protein react to gangliosides with the same specificity as that seen for phospholipids. The $35 \mathrm{kDa}$ fragment releases bound nucleotide when treated with acidic $\mathrm{GM}_{1}$, but not with neutral asialo-GM $\mathrm{GM}_{1}$. Neither the acidic nor neutral gangliosides are able to release ATP from the $29 \mathrm{kDa}$ tryptic fragment (Figure 8).

\section{Discussion}

The activity of DnaA protein probably plays a central role in the timing of primary initiations within the E.coli cell cycle (Skarstad and Boye, 1994; Crooke, 1995). Accumulating evidence suggests that this activity may be modulated by a controlled, reversible conversion between active ATP-DnaK protein and the inactive ADP form. A soluble factor that inactivates DnaA protein specifically for initiation in vitro at oriC is thought to enhance the intrinsic ATPase activity of DnaA protein and, thus, stimulate the shift from ATP-DnaK protein to ADP-DnaK protein (Katayama and Crooke, 1995). A similar negative 
A

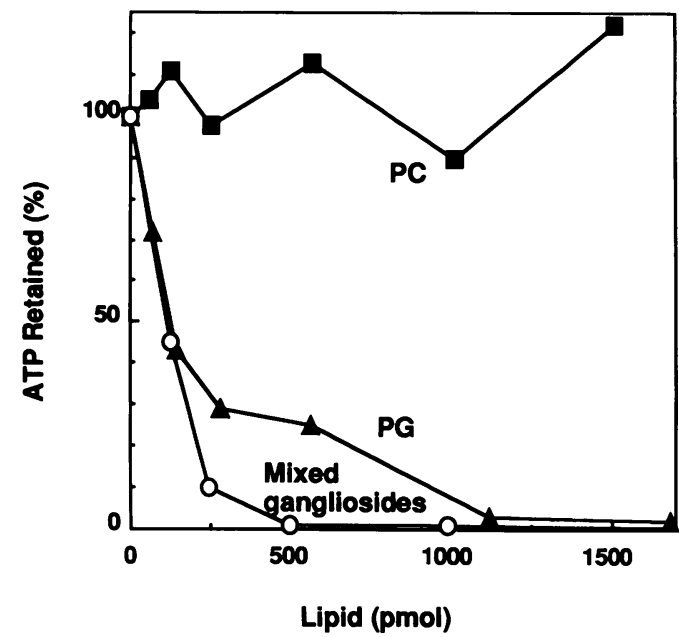

B

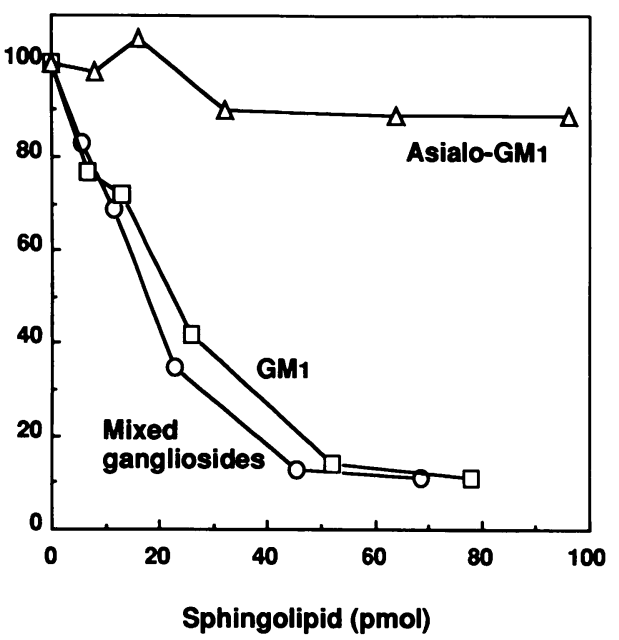

Fig. 7. Acidic sphingolipids promote release of ATP from DnaA protein. (A) [ $\left.{ }^{32} \mathrm{P}\right] \mathrm{ATP}-\mathrm{DnaK}$ protein $(0.2 \mu \mathrm{g}, 16 \mu \mathrm{l}$ buffer A) was treated with phosphatidylglycerol, phosphatidylcholine or mixed bovine brain gangliosides $\left(10 \mathrm{~min}, 38^{\circ} \mathrm{C}\right)$. Protein was collected on nitrocellulose filters, washed with buffer $\mathrm{G}$ and retained ATP was measured by liquid scintillation counting. (B) ATP-DnaK protein $(0.2 \mu \mathrm{g}, 16 \mu 1$ buffer A) was treated with mixed bovine brain gangliosides, $\mathrm{GM}_{1}$, or asialo $\mathrm{GM}_{1},\left(10 \mathrm{~min}, 38^{\circ} \mathrm{C}\right)$ and retained ATP was measured by filter retention. Values of retained $\mathrm{ATP}$ are a percentage of untreated DnaA protein incubated at $38^{\circ} \mathrm{C}$.

effect on the initiation activity of DnaA protein has been proposed for SeqA protein (von Freiesleben et al., 1994).

Conversely, acidic phospholipids in a fluid bilayer are capable of reactivating ADP-DnaK protein complexed with the chromosomal origin by promoting the release of the tightly bound ADP (Sekimizu and Kornberg, 1988; Yung and Kornberg, 1988; Crooke et al., 1992; Castuma et al., 1993). The components necessary for such a rejuvenation of inactive DnaA protein appear to be localized at the cellular membrane. Cell fractionation studies suggest that approximately half of the cellular content of DnaA is associated with membranes (Sekimizu et al., 1988a; Hwang et al., 1990). Immuno-gold labeling of thin sections with anti-DnaA protein antibody clearly localizes a vast majority of the cells' DnaA protein in close proximity with their plasma membrane (E.Crooke, unpublished data). Numerous investigations have also demonstrated that oriC DNA is found in specific fractions of membrane preparations (Nicolaidis and Holland, 1978; Hendrickson et al., 1982; Kusano et al., 1984; Ogden et al., 1988; Jacq et al., 1989; Landoulsi et al., 1990; Chakraborti et al., 1992; Slater et al., 1995).

Here we have attempted to gain insight into the features of DnaA protein and membranes necessary for the exchange of the tightly bound allosteric effectors ADP and ATP. An appreciation that lipid headgroups can regulate the functions of not only integral membrane proteins, but also those of certain extrinsic proteins, is emerging (Newton, 1993). Extrinsic enzymes regulated by acidic phospholipids include SecA protein (Lill et al., 1990; Hendrick and Wickner, 1991), calcineurin (Politino and King, 1987), phosphatidylinositol-4-phosphate kinase (Moritz et al., 1992), protein kinase C (Nishizuka, 1992; Newton, 1993), sphingosine kinase (Olivera et al., 1996) and glycerol-3-phosphate acyltransferase (Scheideler and Bell, 1989). While the activation of protein kinase $C$ is very specific for phosphatidylserine (Newton and Koshland, 1990; Orr and Newton, 1992a,b; Quest and

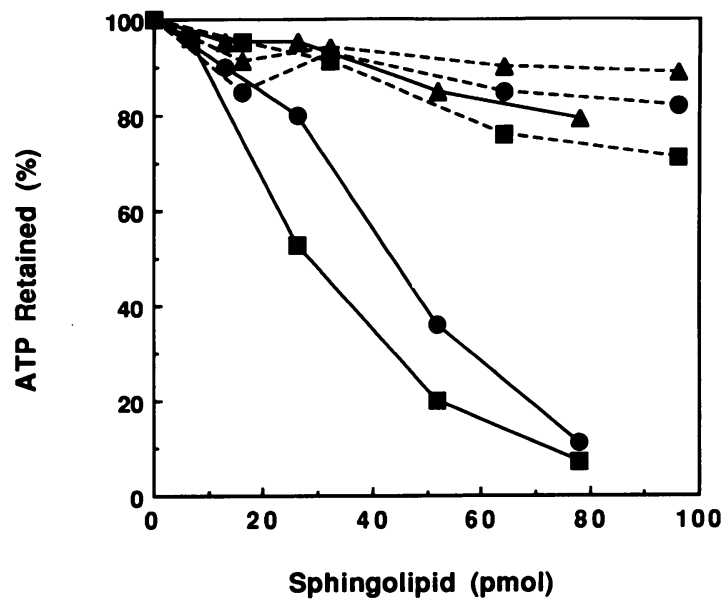

Fig. 8. The proteolytic fragments of ATP-DnaK protein respond specifically to acidic sphingolipids. Full-length [ $\left.{ }^{32} \mathrm{P}\right] \mathrm{ATP}-\mathrm{DnaK}$ protein $(\square)$, the chymotryptic fragment $(\bigcirc)$ and the tryptic fragment (A) $\left(0.2 \mu \mathrm{g}, 16 \mu \mathrm{l}\right.$ buffer A) were treated $\left(10 \mathrm{~min}, 38^{\circ} \mathrm{C}\right)$ with gangliosides asialo-GM $\mathrm{GM}_{1}(----)$ or $\mathrm{GM}_{1}(-)$. Bound ATP levels were measured by filter retention. Values are shown as a percentage of ATP retained by the full-length DnaA protein or the fragments incubated at $38^{\circ} \mathrm{C}$ without lipid.

Bell, 1994), the other enzymes respond to multiple species of acidic phospholipids. An understanding of the nature of the interaction of these proteins with acidic membranes is limiting.

Proteolytic fragments of DnaA protein which retain tightly bound nucleotide were examined for their ability to respond functionally to acidic phospholipids in a manner similar to that for the full-length protein. Two fragments whose amino-termini are within three residues of each other, but differ by their carboxyl ends, show strikingly different behavior when treated with acidic phospholipids (Figure 5). The larger, chymotryptic fragment releases bound nucleotide in the presence of acidic, but not neutral, 
phospholipids. In contrast, the smaller tryptic fragment is inert to both forms of phospholipids. The portion of DnaA protein which is different between the two proteolytic fragments includes a putative amphipathic helix (Figure 3 ). Lys 372 , the likely carboxy-terminus of the tryptic fragment, lies within this sequence and, thus, cleavage of DnaA at this site would most likely disrupt this potential membrane surface-seeking structure.

This region of DnaA protein is protected from digestion by trypsin if the protein is first allowed to associate with vesicles composed of phosphatidylglycerol; no protection is seen with neutral vesicles of phosphatidylcholine. The small, additional protected portion of DnaA protein results in a tryptic fragment $(30 \mathrm{kDa})$ which is responsive to acidic phospholipids (Table II). Thus, a discrete region of $\sim 1-2 \mathrm{kDa}$ is apparently required for DnaA protein to interact functionally with acidic membranes. Cross-linking studies with a radiolabeled photoactivatable phospholipid analog support the hypothesis that this region participates in the association of DnaA protein with membranes. Resolution of fragments generated by chemical cleavage at tryptophans of the DnaA-phospholipid complex with BNPS-skatole [2-(2-nitrophenylsulfenyl)-3-methyl-3'-bromoindolenine] reveal that radiolabel is found solely in a fragment corresponding to residues Gly289-Ser467 of DnaA protein (J.Garner, P.Durrer, J.Brunner and E.Crooke, unpublished data).

In addition to acidic phospholipids, the acidic glycosphingolipid, ganglioside $\mathrm{GM}_{1}$, is active at releasing bound nucleotide from DnaA protein (Figure 7). The similarity in structure of the headgroup of cardiolipin and the phosphodiester backbone of DNA (Rauch et al., 1984) led to speculation that the DNA binding site of DnaA protein may be responsible for binding of acidic phospholipids (Sekimizu and Kornberg, 1988). However, the lack of specificity for acidic phospholipid species and the structurally dissimilar headgroup of $\mathrm{GM}_{1}$ argues against this. It is worth noting that while the $35 \mathrm{kDa}$ chymotrytic fragment most probably contains all but the nine carboxyl amino acids of the domain of DnaA protein shown to be necessary and sufficient for oriC binding (Roth and Messer, 1995), the fragment was ineffective at retaining supercoiled oriC plasmids on nitrocellulose filters (Figure 4). Thus, residues at the extreme carboxyl end of DnaA protein seem critical for origin binding.

ATP-DnaK protein incubated in a mildly acidic buffered solution ( $\mathrm{pH} \mathrm{6.0)} \mathrm{that} \mathrm{also} \mathrm{contains} \mathrm{vesicles} \mathrm{composed} \mathrm{of}$ phosphatidylcholine retains the tightly bound nucleotide (data not shown). Thus, an overall acidic environment is inadequate for triggering DnaA protein to associate functionally with a membrane bilayer. Instead, an acidic surface with an underlying hydrophobic, fluid phase environment appears to be required for exchange of the regulatory molecules ATP and ADP. DnaA protein may be recruited to membranes through electrostatic interaction with the acidic headgroups, followed by insertion of a portion of the protein into the lipid bilayer, an action which triggers the release of bound nucleotide. A similar mechanism of recruitment and binding has been proposed for other peripheral membrane-associating enzymes (Newton, 1993).

Knowledge of the membrane binding site of DnaA protein will aid in the generation of mutant forms of the protein that lack this function. Examination of these mutant DnaA proteins in vitro and in vivo will help clarify the importance of the balance of the nucleotide forms of the protein to the cell cycle and the role the cell membrane plays in controlling chromosomal replication.

\section{Materials and methods}

\section{Materials}

Sources were as follows: HEPES, tricine, CAPS, ATP, $p$-toluene-sulfonylL-arginine methyl ester (TAME), benzoyl-L-tyrosine ethyl ester (BTEE), Sigma; $\left[\alpha-{ }^{32} \mathrm{P}\right] \mathrm{ATP}, 3000 \mathrm{Ci} / \mathrm{mmol}$, Dupont-NEN; [ $\left.{ }^{3} \mathrm{H}\right] S$-adenosylmethionine, $15 \mathrm{Ci} / \mathrm{mmol}$, Amersham; 1-stearoyl-2-oleolyl-sn-glycero-3[phospho-rac-(1-choline)], 1-stearoyl-2-oleolyl-sn-glycero-3-[phosphorac-(1-glycerol)], Avanti Polar Lipids, Inc.; mixed bovine brain gangliosides, $\mathrm{GM}_{1}$, asialo-GM, $\mathrm{GM}_{1}$, Matreya; Mono-Q HR 5/5, Pharmacia; C18 Deltapak ( $300 \AA ., 300 \times 3.9 \mathrm{~mm})$, Waters; trypsin $(500 \mathrm{U} / \mathrm{mg})$, chymotryp$\sin (7.5 \mathrm{U} / \mathrm{mg})$, aprotinin, Boehringer Mannheim; type HA nitrocellulose filters, Immobilon $\mathrm{P}^{\mathrm{SQ}} \mathrm{PVDF}$ membrane, Millipore.

\section{Nucleotide binding to DnaA protein}

DnaA protein in buffer A $[52 \mathrm{mM}$ tricine- $\mathrm{KOH}, \mathrm{pH} 8.25$ at $1 \mathrm{M}$ : $2.5 \mathrm{mM}$ magnesium acetate; $0.323 \mathrm{mM}$ EDTA; $8 \mathrm{mM}$ dithiothreitol (DTT); $0.0065 \%(\mathrm{v} / \mathrm{v})$ Triton X-100; 20\% (v/v) glycerol] was mixed with ATP $(1 \mu \mathrm{M}$; radiolabeled where indicated) and incubated (10 min, $0^{\circ} \mathrm{C}$ ). To quantitate bound nucleotide, samples were filtered through nitrocellulose filters pre-soaked in buffer $\mathrm{G}[50 \mathrm{mM}$ tricine-KOH, $\mathrm{pH} 8.25$ at $1 \mathrm{M} ; 0.5 \mathrm{mM}$ magnesium acetate; $0.3 \mathrm{mM}$ EDTA; $5 \mathrm{mM}$ DTT; $0.005 \%(\mathrm{v} / \mathrm{v})$ Triton X-100; $10 \mathrm{mM}$ ammonium sulfate; $17 \%$ $(\mathrm{v} / \mathrm{v})$ glycerol]. Filters were washed with $5 \mathrm{ml}$ of buffer $\mathrm{G}$, dried, and retained nucleotide was measured by liquid scintillation counting.

\section{DnaA protein binding of oric}

$\left[{ }^{3} \mathrm{H}\right] \mathrm{pBS}$ oriC was prepared by in vitro methylation with $\mathrm{HhaI}$ methylase as described (Yung and Kornberg, 1989). DnaA protein was incubated ( $10 \mathrm{~min}, 25^{\circ} \mathrm{C}$ ) with radiolabeled DNA in buffer DB [25 mM HEPES$\mathrm{KOH}, \mathrm{pH} 7.5$ at $1 \mathrm{M} ; 0.5 \mathrm{mM}$ magnesium acetate; $0.3 \mathrm{mM}$ EDTA; $5 \mathrm{mM}$ DTT; $0.005 \%(\mathrm{v} / \mathrm{v})$ Triton X-100;20\% (v/v) glycerol]. To quantitate retained DNA, samples were filtered through nitrocellulose filters pre-soaked in buffer DB. Filters were washed with $5 \mathrm{ml}$ of buffer $\mathrm{DB}$, dried, and retained DNA was measured by liquid scintillation counting.

\section{Isolation of proteolytic fragments by reverse phase chromatography}

Proteolysis reactions were diluted with 4 volumes of $0.1 \%$ trifluoroacetic acid (TFA) and clarified by centrifugation $\left(10 \mathrm{~min}, 140000 \mathrm{~g}, 4^{\circ} \mathrm{C}\right)$ and loaded onto a Deltapak C 18 column $(300 \AA, 300 \times 3.9 \mathrm{~mm}$; equilibrated in $0.1 \%$ TFA, room temperature). A gradient $(30 \mathrm{~min}, 1 \mathrm{ml} / \mathrm{min}$ ) of $0-70 \%$ acetonitrile (in $0.1 \%$ TFA), was started immediately following sample injection. Peak fractions were collected, dried in vacuo and resuspended in formic acid $(88 \%)$ :ethanol $(95 \%)(7: 3 ; 10 \mu \mathrm{l})$. Samples of the resuspended fragments were analyzed by SDS-PAGE and mass spectroscopy ( 2.5 and $7.5 \mu \mathrm{l}$, respectively).

\begin{abstract}
Membrane preparation
Phosphatidylglycerol and phosphatidylcholine in $\mathrm{CHCl}_{3}$ were dried under a stream of nitrogen gas and suspended in water by sonication $(15 \mathrm{~min}$, $0^{\circ} \mathrm{C}$ ) with $30 \%$ bursts with a microtip probe sonicator (Branson). Sonicated lipids were centrifuged $\left(10 \mathrm{~min}, 140000 \mathrm{~g}, 4^{\circ} \mathrm{C}\right)$, and the supernatant, which contains small unilamellar vesicles, was collected. Phospholipids were quantitated by a phospho-polymolybdate colorimetric assay (Ames and Dubin, 1960). Sphingolipids were prepared by suspending the powdered gangliosides in distilled water and storing in liquid nitrogen.
\end{abstract}

\section{Other methods}

Transfer of fragments from SDS-polyacrylamide gel to PVDF membrane was performed as described (Matsudaira, 1987). DnaA protein was purified (Sekimizu et al., 1988b) from BL21(DE3)pLysS/pKA211, a transformed strain in which high level inducible expression of the wildtype dnaA gene is under control of a bacteriophage T7 RNA polymerase promoter (T.Katayama, unpublished data). Protein quantitation was performed as described (Bradford, 1976). The proteolytic activity of chymotrypsin was determined by hydrolysis of BTEE as described 
(Worthington, 1988). Trypsin activity was measured by hydrolysis of TAME as described (Worthington, 1988). Amino acid analysis and $\mathrm{N}$-terminal sequencing was performed by Dr A.Fowler, UCLA Protein Microsequencing Facility, SDS-PAGE and silver staining was as described (Crooke et al., 1988).

\section{Acknowledgements}

We thank our collaborators Hiroshi Nakai (Georgetown University), Kirsten Skarstad (Radiumhospital, Oslo) and Nick Dixon (Australian National University), with whom we maintain and share a supply of E.coli replication proteins. We thank Tsutomo Katayama for providing us with the DnaA protein-overproducing plasmid pKA211 (unpublished data). We also thank H.Nakai and Sarah Spiegel for critical reading of the manuscript, and Preston Hensley (SmithKline Beecham Pharmaceuticals) for his discussion on analysis of mass spectroscopy data. We acknowledge Audree Fowler of the UCLA Protein Microsequencing Facility, which is partially supported by a Cancer Center Support Grant from the NCI (\#CA 16042-20) to the Jonsson Comprehensive Cancer Center. This work was supported in part by National Institutes of Health Grant GM49700 and National Science Foundation Grant MCB9408830 (to E.C.).

\section{References}

Ames,B.V. and Dubin,D.T. (1960) The role of polyamines in the neutralization of bacteriophage deoxyribonucleic acid. J. Biol. Chem., 235, 769-775.

Bradford,M. (1976) A rapid and sensitive method for the quantitation of microgram quantities of protein utilizing the principle of proteindye binding. Anal. Biochem., 72, 248-254.

Bramhill,D. and Kornberg,A. (1988) Duplex opening by DnaA protein at novel sequences in initiation of replication at the origin of the E.coli chromosome. Cell, 52, 743-755.

Castuma,C.E., Crooke,E. and Kornberg,A. (1993) Fluid membranes with acidic domains activate DnaA protein, the initiator protein of replication in Escherichia coli. J. Biol. Chem., 268, 24665-24668.

Chakraborti,A., Gunji,S., Shakibai,N., Cubeddu,J. and Rothfield,L. (1992) Characterization of the Escherichia coli membrane domain responsible for binding oriC DNA. J. Bacteriol., 174, 7202-7206.

Crooke,E. (1995) Regulation of chromosomal replication in E.coli: sequestration and beyond. Cell, 82, 877-880.

Crooke,E., Guthrie,B., Lecker,S., Lill,R. and Wickner,W. (1988) ProOmpA is stabilized for membrane translocation by either purified E.coli trigger factor of canine signal recognition particle. Cell, 54, 1003-1011.

Crooke,E., Castuma,C.E. and Kornberg,A. (1992) The chromosome origin of E.coli stabilizes DnaA protein during rejuvenation by phospholipids. J. Biol. Chem., 267, 16779-16782.

Crooke,E., Thresher,R., Hwang,D.S., Griffith,J. and Kornberg,A. (1993) Replicatively active complexes of DnaA protein and the Escherichia coli chromosomal origin observed in the electron microscope. J. Mol. Biol., 233, 16-24.

Fujita,M.Q., Yoshikawa,H. and Ogasawara,N. (1992) Structure of the dnaA and DnaA-box region in the Mycoplasma capricolum chromosome: conservation and variations in the course of evolution. Gene, 110, 17-23.

Funnel,B., Baker,T. and Kornberg,A. (1986) Complete enzymatic replication of plasmids containing the origin of the Escherichia coli chromosome. J. Biol. Chem., 261, 5616-5624.

Hansen,F., Koefoed,S. and Atlung,T. (1992) Cloning and nucleotide sequence determination of twelve mutant dnaA genes of Escherichia coli. Mol. Gen. Genet., 234, 14-21.

Heacock,P.N. and Dowhan,W. (1989) Alteration of the phospholipid composition of Escherichia coli through genetic manipulation. J. Biol. Chem., 264, 14972-14977.

Hendrick,J.P. and Wickner,W. (1991) SecA protein needs both acidic phospholipids and SecY/E protein for functional high-affinity binding to the Escherichia coli plasma membrane. J. Biol. Chem., 266, 24596-24600.

Hendrickson,W., Kusano,T., Yamaki,H., Balakrishnan,R., King,M., Murchie,J. and Schaechter,M. (1982) Binding of the origin of replication of Escherichia coli to the outer membrane. Cell, 30, 915-923.

Hwang,D.S. and Kaguni,J.M. (1988a) Purification and characterization of the dnaA46 gene product. J. Biol. Chem., 263, 10625-10632.
Hwang,D.S. and Kaguni,J.M. (1988b) Interaction of dnaA46 protein with a stimulatory protein in replication from the Escherichia coli chomosomal origin. J. Biol. Chem., 263, 10633-10640.

Hwang,D.S. and Kornberg,A. (1992) Opening of the replication origin of Escherichia coli by DnaA protein with the proteins HU or IHF. J. Biol. Chem., 267, 23083-23086.

Hwang,D.S., Crooke,E. and Kornberg,A. (1990) Aggregated DnaA protein is dissociated and activated for DNA replication by phospholipase or DnaK protein. J. Biol. Chem., 265, 19244-19248.

Jacq,A., Kern,R., Tsugita,A. and Kohiyama,M. (1989) Purification and characterization of a low molecular weight membrane protein with affinity for the Escherichia coli origin of replication. J. Bacteriol., 171, 1409-1416.

Katayama,T. and Crooke,E. (1995) DnaA protein is sensitive to a soluble factor and is specifically inactivated for initiation of in vitro replication of the Escherichia coli minichromosome. J. Biol. Chem., 270, 9265-9271.

Kusano,T., Steinmetz,D., Hendrickson,W., Murchie,J., King,M., Benson,A. and Schaechter,M. (1984) Direct evidence for specific binding of the replicative origin of the Escherichia coli chromosome to the membrane. J. Bacteriol., 58, 313-316.

Landoulsi,A., Malki,A., Kern,R., Kohiyama,M. and Hughes,P. (1990) The E.coli cell surface specifically prevents the initiation of DNA replication at oriC on hemimethylated DNA templates. Cell, 63, 1053-1060.

Lill,R., Dowhan,W. and Wickner,W. (1990) The ATPase activity of SecA is regulated by acidic phospholipids, SecY, and the leader and mature domains of precursor proteins. Cell, 60, 271-280.

Marians,K.J. (1992) Prokaryotic DNA replication. Annu. Rev. Biochem., 61, 673-719.

Masai,H., Nomura,N. and Arai,K. (1990) The ABC primosome: a novel priming system employing dnaA, dnaB, dnaC, and primase on a hairpin containing a dnaA box sequence. J. Biol. Chem., 265, 15134-15144.

Matsudaira,P. (1987) Sequence from picomole quantities of proteins electroblotted onto polyvinylidene diflouride membranes. J. Biol. Chem., 262, 10035-10038.

Moritz,A., De Graan,P.N., Gispen,W.H. and Wirtz,K.W. (1992) Phosphatidic acid is a specific activator of phosphatidylinositol-4phosphate kinase. J. Biol. Chem., 267, 7207-7210.

Newton,A. (1993) Interaction of proteins with lipid headgroups: lessons from protein kinase C. Annu. Rev. Biophys. Biomol. Struct., 22, 1-25.

Newton,A. and Koshland,D.E.,Jr (1990) Phosphatidylserine affects specificity of protein kinase $\mathrm{C}$ substrate phosphorylation and autophosphorylation. Biochemistry, 29, 6656-6661.

Nicolaidis,A. and Holland,I. (1978) Evidence for the specific association of the chromosomal origin with outer membrane fractions isolated from Escherichia coli. J. Bacteriol., 135, 178-189.

Nishizuka,Y. (1992) Intracellular signaling by hydrolysis of phospholipids and activation of protein kinase C. Science, 258, 607-614.

Ogawa,T., Pickett,G.G., Kogoma,T. and Kornberg,A. (1984) RNase H confers specificity in the $d n a A$-dependent initiation of replication at the unique origin of the Escherichia coli chromosome in vivo and in vitro. Proc. Natl Acad. Sci. USA, 81, 1040-1044.

Ogden,G., Pratt,M. and Schaechter,M. (1988) The replicative origin of the E.coli chromosome binds to cell membranes only when hemimethylated. Cell, 54, 127-135.

Olivera,A., Rosenthal,J. and Spiegel,S. (1996) Effect of acidic phospholipids on sphingosine kinase. J. Cell Biochem., in press.

Orr,J.W. and Newton,A. (1992a) Interaction of protein kinase C with phosphatidylserine. 1. Cooperativity in lipid binding. Biochemistry, 31, 4661-4667.

Orr,J.W. and Newton,A. (1992b) Interaction of protein kinase C with phosphatidylserine. 2. Specificity and regulation. Biochemistry, 31, 4668-4673.

Politino,M. and King,M.M. (1987) Calcium- and calmodulin-sensitive interactions of calcineurin with phospholipids. J. Biol. Chem., 21, 10109-10113.

Quest,A.F. and Bell,R.M. (1994) The regulatory region of protein kinase $\mathrm{C}$ gamma. Studies of phorbol ester binding to individual and combined functional segments expressed as glutathione-S-transferase fusion proteins indicate a complex mechanism of regulation by phospholipids, phorbol esters, and divalent cations. J. Biol. Chem., 269, 20000-20012.

Rauch,J., Tannenbaum,H., Stollar,B.D. and Schwartz,R.S. (1984) Monoclonal anti-cardiolipin antibodies bind to DNA. Eur. J. Immunol., 14, 529-534. 
Roth.A. and Messer.W. (1995) The DNA binding domain of the initiator protein DnaA. EMBO J., 14, 2106-2111.

Scheideler,M.A. and Bell,R.M. (1989) Phospholipid dependence of homogeneous, reconstituted $s n$-glycerol-3-phosphate acyltransferase of Escherichia coli. J. Biol. Chem., 21, 12455-12461.

Sekimizu,K. and Kornberg,A. (1988) Cardiolipin activation of dnaA protein, the initiation protein of replication in Escherichia coli. J. Biol. Chem., 263, 7131-7135.

Sekimizu,K.. Bramhill,D. and Kornberg,A. (1987) ATP activates DnaA protein in initiating replication of plasmids bearing the origin of the E. coli chromosome. Cell, 50, 259-265.

Sekimizu,K., Bramhill,D. and Kornberg,A. (1988a) Sequential early stages in the in vitro initiation of replication at the origin of the Escherichia coli chromosome. J. Biol. Chem., 263, 7124-7130.

Sekimizu,K., Yung,B.Y.M. and Kornberg,A. (1988b) The DnaA protein of Escherichia coli: abundance, improved purification, and membrane binding. J. Biol. Chem., 263, 7136-7140.

Skarstad,K. and Boye.E. (1994) The initiator protein DnaA: evolution, properties and function. Biochim. Biophys. Acta, 1217, 111-130.

Slater.S., Wold.S., Lu.M., Boye,E., Skarstad,K. and Kleckner,N. (1995) E.coli SeqA protein binds the DNA replication origin in two different methyl-modulated reactions appropriate to its roles in replication initiation and origin sequestration. Cell, 82, 927-936.

Torrey,T., Atlung,T. and Kogoma,T. (1984) dnaA suppressor (dasF) mutants of Escherichia coli are stable DNA replication (sdrA/rnh) mutants. Mol. Gen. Genet., 196, 350-355.

von Freiesleben,U., Rasmussen,K.V. and Schaechter,M. (1994) SeqA limits DnaA activity in replication from oriC in Escherichia coli. Mol. Microbiol., 14, 763-772.

von Meyenburg,K., Boye,E., Skarstad,K., Koppes,L. and Kogoma,T. (1987) Mode of initiation of constitutive stable DNA replication in RNase H-defective mutants of Escherichia coli K-12. J. Bacteriol., 169. 2650-2658.

Worthington,C.C. (ed.) (1988) Worthington Enzyme Manual. Worthington Biochemical Corporation, Freehold, NJ.

Yung,B.Y.M. and Kornberg,A. (1988) Membrane attachment activates DnaA protein, the initiation protein of chromosome replication in Escherichia coli. Proc. Natl Acad. Sci. USA, 85, 7202-7205.

Yung.B.Y.M. and Kornberg,A. (1989) The dnaA initiator protein binds separate domains in the replication origin of Escherichia coli. J. Biol. Chem., 264, 6146-6150.

Yung.B.Y.M., Crooke.E. and Kornberg,A. (1990) Fate of the DnaA initiator protein in replication at the origin of the Escherichia coli chromosome in vitro. J. Biol. Chem., 265, 1282-1285.

Xia.W. and Dowhan,W. (1995) In vivo evidence for the involvement of anionic phospholipids in initiation of DNA replication in Escherichia coli. Proc. Natl Acad. Sci. USA, 92, 783-787.

Received on November 6, 1995; revised on January 5, 1996 